\title{
An Exploration on The Use of Podcast in Speaking Class
}

\author{
Agustina Lestary \\ STKIP PGRI Banjarmasin, Banjarmasin
}

aqustinalestary@stkipbjm.ac.id

\begin{abstract}
The objective of this study is to describe the use of podcast in a speaking classroom. This study is also intended to elaborate students' perspective while using podcast. It is expected that the result of this study will provide a better insight towards students' point of view regarding speaking in general and the use podcast in specific.

This study is a descriptive study with a qualitative approach. The subjects of this study are students at STKIP PGRI Banjarmasin who are taking Academic Speaking course. The students are required to broadcast podcasts throughout the course and fill in a questionnaire at the end of the semester. The use of podcast will be explained and the response of the questionnaire will be analyzed.

The result of this study shows that students find podcast is a helpful activity to help them with their speaking practice. The fact that podcast reduce the direct contact to the audience helps the students to reduce their anxiety and boost their confidence. By the end of the day, the students find it is quite comfortable to speak in English through podcast.
\end{abstract}

Keywords: speaking English, EFL, podcast, teaching speaking, monologue

\section{INTRODUCTION}

Being a foreign Language, teaching English has always been a challenge for many teachers and lecturers. Even with easier access to many resources with the current technology, the teachers' job in teaching English to Indonesian students is not getting any easier, if not even more difficult. The lack of vocabularies has been one of the many reasons of why students cannot learn English successfully (Ratnasari, 2020). This problem will hinder the students in improving their writing, reading, listening, and speaking skill. Yet, the vocabularies is not the only issues that need to be addressed if the focus of the study is speaking skill.

There are at least three key points that should be addressed properly when it comes to teaching English Speaking skill in EFL (English as Foreign Language) 
classroom; the nature of speaking, the students' perspective and the teachers' knowledge. These three points should not be overlooked when the teachers designing the classroom activities or when researchers trying to offer solutions to teaching speaking issues.

As it is widely known, speaking is a complex skill to master. Oral communication is a two-way interaction which requires both production ability and comprehension ability. Language learners are expected to utter sentences with not only correct grammar but also pronunciation. They are also inquired to apply speaking strategies as they speak. At the very same time, learners are also required to understand the spoken information in order to produce proper response. These are not the ability ones can easily acquire. Unfortunately, many studies have shown that EFL learners in Indonesia are still lack of oral English proficiency. The proficiency includes vocabularies, grammar, pronunciation, etc. (Widiati \& Cahyono, 2006).

Further, it is also important to take the students' perspectives into account when it comes to teaching speaking. Nazara (2011) explained that many English learners are afraid of their teachers. Students usually find it is sometimes uncomfortable when their teachers correct their grammar or pronunciation directly. The learners are sometimes also feeling shy when they speak with or in front of their friends. They might feel insecure with their own English and fear of being a laughing object. Thus, the discussion on how to overcome the psychological problems, such as anxiety, stage freight, and confidence is needed as much as the discussion related to language focus or material. In addition, students' willingness as well as motivation in learning are also important issues to address (Abadi, 2015; Bouzar, 2019; Nuraini, 2016).

Considering the complexity of skill required in oral communication and the students' psychological state, it is essential for the teachers or lecturers to design a speaking class where the students do not only learn how to speak in English but also learn how to speak in public in the very first place. Teachers are encouraged to learn as many techniques and activities as possible and try to implement them in their classrooms to find out which one fits their students the most. Teaching process, for sure, is a never ending cycle of trial and error with the objective of providing the best 
learning environment for the students. Abadi (2015) stated that teachers' training experiences, along with the teaching skills will contribute to how the teachers conduct their teaching and learning process.

Numerous studies related to techniques and activities in teaching speaking skill have been conducted and published for the teachers to be explored and implemented in their classrooms. A recent study by Argawati (2014) suggested group discussion as effective technique to improve students' speaking skill. Through group discussion, the students can participate actively in speaking activity. In addition, they will also learn some social skill. Similar to Argawati (2014), Khusniyah (2019) applied peer teaching method in teaching speaking skill. This method allows students to have interaction with other students through which they will evaluate each other and try to find any solutions together for their problems. Further, Zuhriyah (2017) offered another technique that can help students to learn speaking English which is storytelling. In her study, the students showed many improvements, such as their comprehension, fluency, grammar, vocabulary, and pronunciation after two cycles of implementation.

The researcher realized that many studies related to teaching speaking skill focus mainly on the tangible result - the improvement that they can measure. As much as it is important to reach certain objectives or measure the improvement made by the students, it is also necessary to analyze the use of a technique from students' perspective. Researchers (or teachers) should also evaluate what makes a technique helpful for the students.

Moreover, many studies related to speaking also focus on having the students doing conversation with their friends or in front of the class only (Argawati, 2014; Khusniyah, 2019; Zuhriyah, 2017). As much as it is important for the students to experience two-way conversations or to use their language knowledge in real life basis, the researcher deems it is urgent as well to build learners' self-confidence. Xu (2011) explored how self-confidence could influence the speaker's communicative competence. Self-confidence may influence learners' eagerness to involve 
themselves in conversations and also to build communication. The researcher believes that teachers should take into consideration both learners' language knowledge and psychological readiness when it comes to choosing techniques, methods, or activities to improve the students' speaking skill.

Thus, this research is conducted under the research question of, "how does podcast help students to improve their speaking skill? "Podcast itself is a modern version of monologue or storytelling. Some applications are available to record and broadcast podcasts. The objective of this study is to describe the use of Anchor as the medium of podcast in teaching speaking to students in EFL classroom. The researcher will also explore how podcast can help students in practicing their speaking skill and somewhat lead to boost their self-confidence. The aim of this study is not measuring the students' improvement but more about exploring what makes podcast helpful for the students.

\section{METHODS}

Descriptive analyses are central to almost every research project. Whether the goal is to identify and describe trends and variation in populations, create new measures of key phenomena, or simply describe samples in studies aimed at identifying causal effects, descriptive analyses are part of almost every empirical paper and report.

This study is a descriptive research as it emphasizes on the in-depth exploration of teacher and students' experience in an EFL classroom. As explained by Loeb et al. (2017), among many goals of a descriptive study is to identify and describe trends or samples in studies. Further, this study employed qualitative approach. Creswell (2013) stated that a qualitative study gather data in multiple forms, such as through interviews, observations, and documents review.

The data were obtained from the fourth semester students of English Department of STKIP PGRI Banjarmasin. There were 32 students. The data were the students' recording and questionnaire result. Seven topics were given to students, ranging from personal related topics to world affair topics, in the duration of seven weeks. The students were required to recorded their responses related to the topics and 
uploaded them at Anchor app. At the end of the semester, the students were requested to fill in a questionnaire related to the activity.

\section{RESULT AND DISCUSSION}

Introduced around 2015, Anchor is a platform where the users can broadcast audio in short-form. However, the company launched the up dated version of the platform which allows longer audio and easier way to broadcast. Later in 2019 , the platform is acquired by Spotify and make it easier for listeners to listen to the podcasts (Perez, 2018). Cambridge Dictionary defines podcast as a broadcast share on the internet for anyone to listen.

Taken the advantage that podcast is a form of monologue, and the fact that the platform of Anchor itself is free to use and can be accessed through different applications, the researcher decided to use Anchor as part of speaking class activity. Later, at the end of the class, the students were required to answer questionnaire about the use of the Anchor. The researcher documented seven podcasts that had been recorded by 32 students in 7 weeks. The topics were varied from current affair to personal story.

Anchor is an easy-to-use application. With its many friendly-user features, users can record, edit, insert songs and broadcast the podcasts. The first podcasts were broadcasted by the students on March 23rd, 2020, and the last ones were broadcasted on June 3rd, 2020 as part of speaking activities in Academic Speaking class. The topics given were the students' strength and weakness, the students' past, present and future, books and movies recommendation, best moments in life, superpower, college life and feminism. The podcasts should be around 20 to 30 minutes.

Although they were required to share the link to their podcasts on the on-line classroom, there were no obligation for the students to share their recordings to other listeners. The researcher gave comment regularly to each podcast related to the content of the podcast itself. It is considered as necessary action to make sure that the students felt appreciated and listened to. 
By the end of the semester, the researcher requested the students to fill in a questionnaire regarding their experience in doing podcast. The questionnaire was also intended to explore how the application or the activity of doing podcast itself help them with their speaking skill. Each question of the questionnaire and the response are explained below. There were 32 students taking part in Academic Speaking class and did the podcasts but there were only 29 students filled out the questionnaire. Due to some technical issues that might occur when the students responding to the questionnaire, some questions were left unanswered by the students. Thus, readers might expect varied number of respondents in each question.

Question 1. Did you prepare a script or outline before recording?

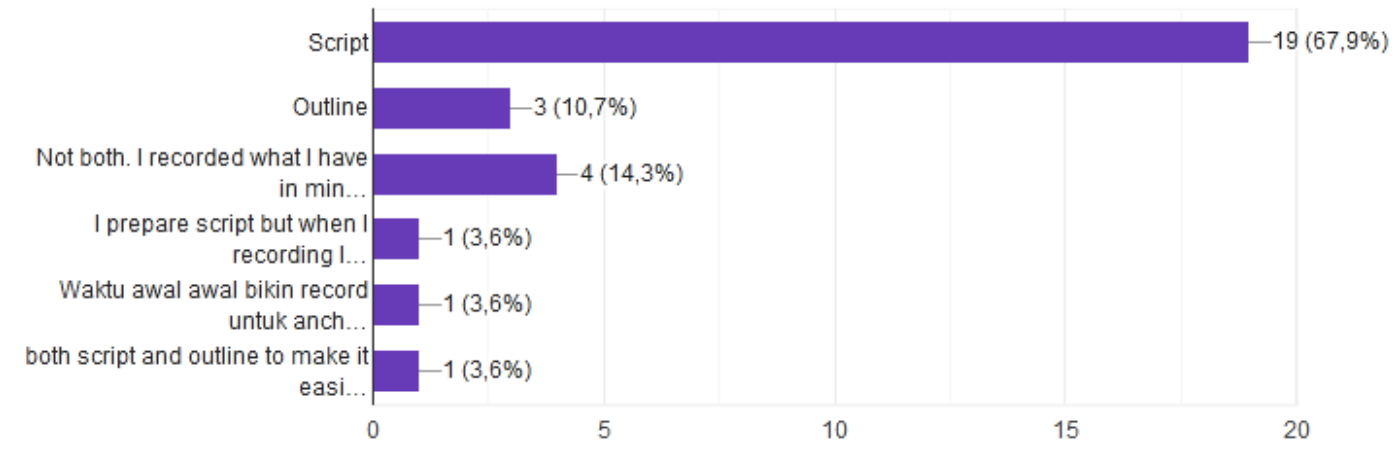

Figure 1. Answer to question 1, "did you prepare a script or outline before recording? "

Based on the diagram above, it can be seen that most students prepared script before they did the recording. On the other hand, surprisingly, some other did not prepare any script nor outline. Few students also mentioned that they did prepare script or outline during the first few recordings but they started doing the podcast without any script or outline as they got better grip of the activity. Despite the fact that most of the students used some scripts as their guidelines during the recording, the researcher noticed that most of the podcasts sound natural. The students did not sound as if they were reading and more of telling stories.

Question 2. Did you practice before recording? 


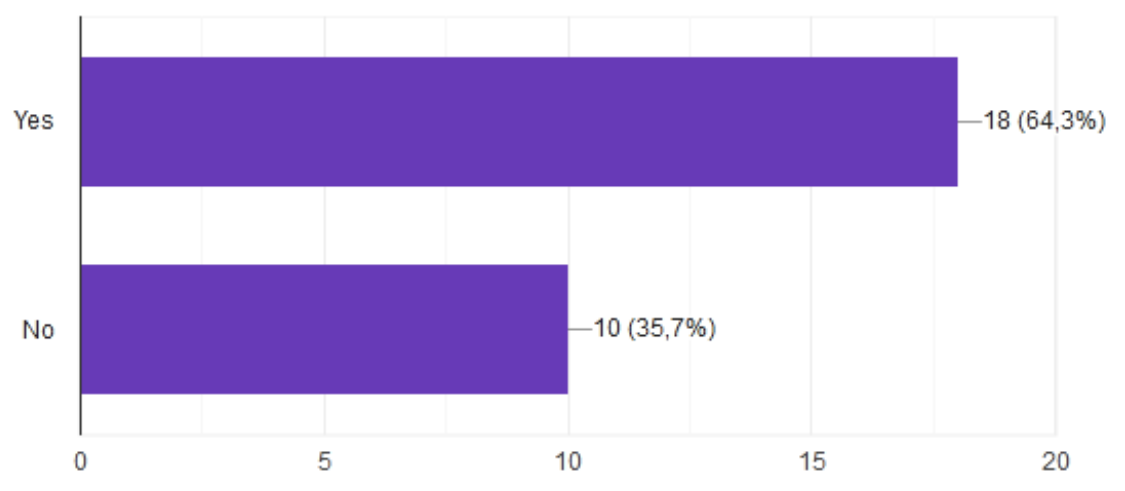

Figure 2. Answer to question 2, "did you practice before recording? "

It can be seen from the diagram above that almost all of the students did some practice before recording. However, the researcher was unable to ask follow up question on how they did the practice. The diagram also shows us that some students were confident enough that they did not feel the need of practicing before hitting the record button.

Question 3. Did you do some research or look up on the internet before your recording?

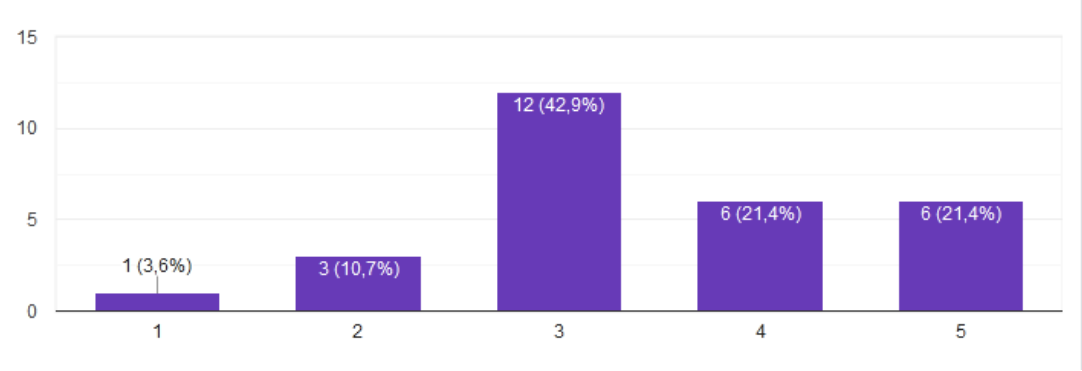

Figure 3. Answer to question 3, "did you do some research or look up on the internet before your recording?"

With option number 1 means never and option number 1 means always, most students chose option number 3 . This means that most students often did some research or looked up on the internet related to the topic given. Given that some topics were related to current affairs and global issues, the researcher find it is understandable that the students looked up on the internet for some reference.

Question 4. How long did it usually take for you to prepare your recording? 


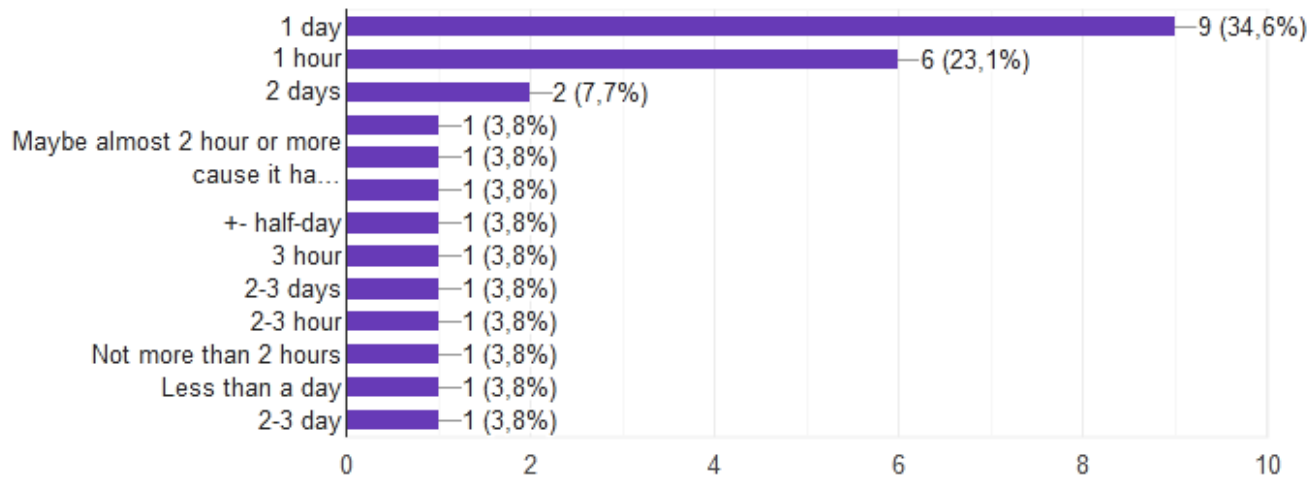

Figure 4. Answer to question 4, "how long did it usually take for you to prepare your recording?"

Based on the diagram above, it can be seen that most students needed around one day to prepare for their recordings. The preparation might be related to the questions before, from doing some research on the internet, preparing script, to practicing. The rest students provided varied response related to their preparation, from 2-3 days to one hour.

Question 5. Did you feel comfortable talking by yourself and recorded?

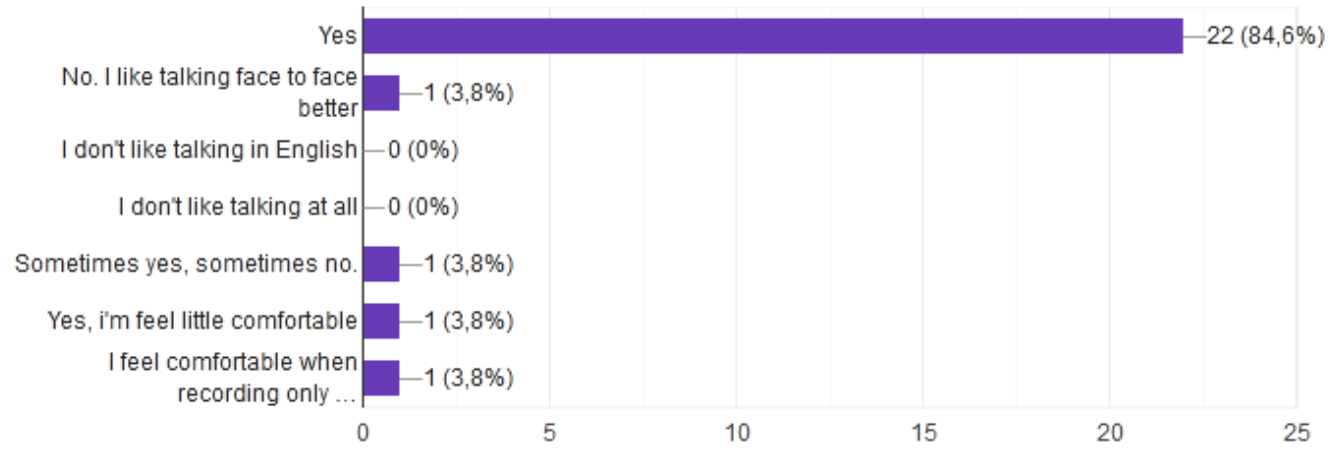

Figure 5. Answer to question 5, "did you feel comfortable talking by yourself and recorded?"

Based on the diagram above, it can be seen that the students did not find any problem in speaking in English. The absence of audience or the feeling that they were not being the center of attention might help them in speaking more comfortably. As the diagram shows, no students said that they did not like talking in English. This means that the students who are usually quiet in speaking class do not necessarily mean that they are bad in English or do not like talking at all. There might be some other reasons of why students refuse to involve actively in speaking class. 
Question 6. Of all the topics that we had, which one (s) you like the most? You may choose more than one

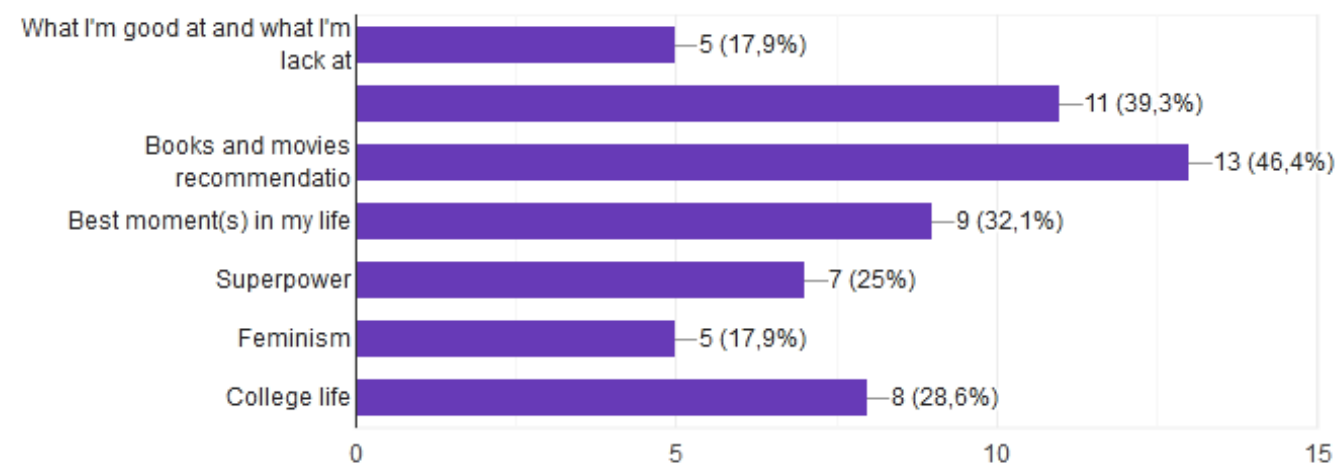

Figure 6. Answer to question 6, "of all the topics that we had, which one (s) you like the most? You may choose more than one".

Based on the diagram above, it can be seen that general topic such as books and movies are the most favorite topic to discuss, followed by more personal topic such as past-me, present-me, and future-me. Meanwhile, the global issues such as feminism is the least favorite one.

\section{Question 7. Why did you choose the topic(s)}

Question number 7 is related to the question number 6 . The students are requested to provide reason(s) on why certain topic is more interesting for them than the other. The students find it is more interesting to talk about the topics that are close to their home ground, such as about favorite movie or books, or college life. They also stated that they could reflected on their personal lives and feelings through some topics, such as strength and weakness, and past-me, present-me and futureme. However, there were also few students that found the topic of feminism was interesting enough. Many students found it was quite difficult to discuss about the current affairs because they had to do some research first before the recordings. But some others stated that they could learn many new things by having these kinds of topics for the podcast.

Question 8. Did you usually share your recordings to your friends? 

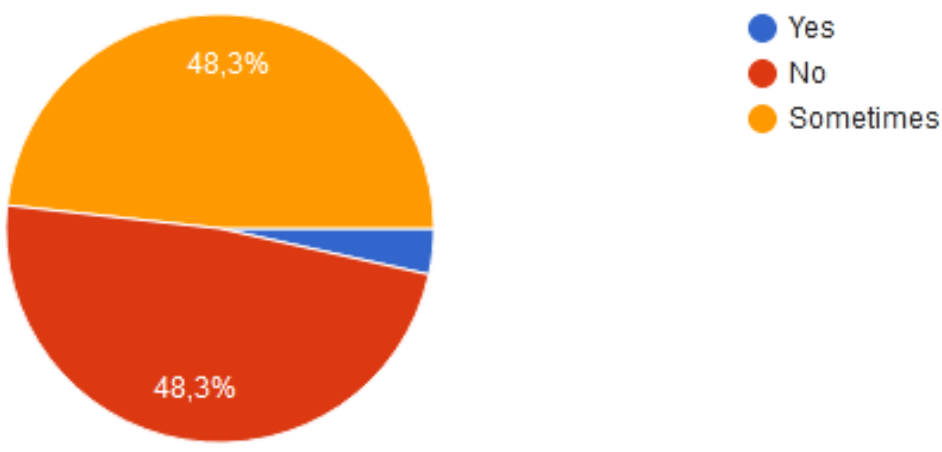

Figure 7. Answer to question 8, "did you usually share your recordings to your friends "?

The diagram shows that some students did not share their recordings to their friends. They only posted the link to their podcasts on the room at Edmodo specifically created for Academic Speaking class. However, some other students shared their podcasts to more listeners. The recording published at Anchor could be shared to other platforms, such as Spotify or Google podcast. The reasons of why or why not the students shared their podcasts to other listeners could be found on the next question.

\section{Question 9. Why did you or did you not share your recordings to your friends?}

The answers of this questions were quite varied. Some students shared the link of their podcasts to other people so that the listeners could give some advice and feedback about their English. Other students said that they had no particular reason. It was just they wanted people to hear their stories and people would know what the students were studying at campus. On the other hand, the main reason of why some other students did not share their podcasts was because they were not that confidence. They still felt that they had lack of vocabularies and bad pronunciation. Thus, they did not want people to notice their shortcomings.

Question 11. Did you usually listen to your own recording? 


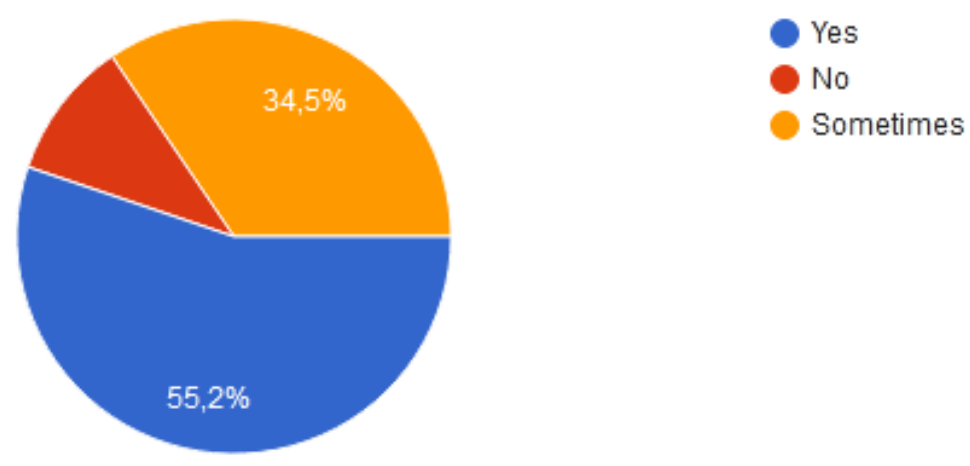

Figure 8. Answer to question 11, "did you usually listen to your own recording? "

The researcher gave the question in order to find out if the students did some selfevaluation. Fortunately, most students listened to their own recordings. By doing so, they could find what they were still lack of and what they could improve. Listening to their own recordings could also help them assessing their own improvement in every recording.

\section{Question 12. How was your first recording different from your last recording?}

Most students admitted that the first few recordings were the most difficult ones but they were getting better later. There are few reasons of why they found it is hard. The first reason is because they were not familiar with Anchor yet so they need time to learn about the features. Second, some students found that speaking in 15 to 20 minutes was not easy. They were running out of things to say. The last reason is because of the limited vocabulary. However, many students stated that the recording was getting easier once they got used to it or when the topics given were related to their personal lives.

Question 13. Do you think the podcast helps you in improving your English-speaking skill? Please give brief explanation

It is glad to find out that the students like doing the podcasts. They could practice their English, especially pronunciation. They did admit that because of the recording, they eventually checked on the dictionary to consult on how to pronounce certain words. They also listened to their own recordings to make sure they got the correct 
pronunciation. In addition, preparing for the podcasts allowed them to learn some new vocabularies. They were also somehow being forced to do some research on the internet, especially when it came to general affairs. Some students also said that they initially did not believe in themselves but by the end of the day, they could do the recordings quite well.

Nevertheless, the researcher realized that no feedback was given. The researcher did give some comments but they were more about the content of the podcasts and not about the pronunciation or other grammatical issues. Students believed that this feedback is actually necessary so that they can learn from their mistakes.

\section{Question 14. What do you think is the biggest problem when you are speaking?}

There are three main problems that the students mentioned when it comes to speaking in English. The first is pronunciation. As English is not their native speaker and not even a second language - it is understandable that many learners are insecure about their own pronunciation. Even checking on the dictionary or listen to some on line dictionary sometimes is not enough. The second problem is vocabularies. The students felt that they did not have adequate vocabularies and many times they had problem in expressing their opinion or telling stories because they could not find the right words to express themselves. The last problem is being spontaneous. It is most likely related to the fact that they have limited vocabularies so that they cannot talk freely. This is also probably the reason of why students were more comfortable in having a script or outline when they were recording the podcasts.

The findings above are in line with other studies. As mentioned by Widiati and Chayono (2006) and Ratnasari (2020), lack of vocabularies, grammatical error, and incorrect pronunciation are among many problems faced by the students in speaking English. These problems are also experienced by the students of STKIP PGRI Banjarmasin as the subject of the study.

The researcher would highly suggest to use podcast to help students in practicing their English speaking skill. The activity can help students to reduce anxiety and boost 
their self-confidence. As mentioned in many studies, many students experience psychological issues such as having anxiety (Abadi, 2015; Bouzar, 2019; Nuraini, 2016). Further, Xu (2011) also emphasized how important self-confidence in speaking practice is. Based on the questionnaire conducted, there are two main reasons of why Podcast can help students to overcome the issues of anxiety and lack of confidence.

First, podcast allows students to prepare themselves. Indrianty (2016) stated that lack of preparation is one of the sources of students' anxiety when they speak English. As mentioned above, the students can do some research related to the topic they are going to talk about. They also have enough time to write some script or outline of what they are going to say. As they write the script, they can look up to dictionary for some words that they do not know or some pronunciation of words they are not familiar with. They can also listen to practice their speaking before doing real recording. Even after they finished recording the podcast, they can still listen to what they have recorded and redo the process if they find their recording is not good enough.

Speaking practice such as delivering speech or debate might allow some time for preparation but it does not give the chance for the students to correct themselves. It is in line with Siagian and Adam (2017) who mentioned that the fear of making mistakes could trigger students' anxiety. To put it simply, podcast gives them time and chance. Time to do some preparation and chance to correct themselves. These are two things that students might not find when they do the speaking practice with their friends or with their teachers.

Second, podcast can help students to boost their confidence in speaking by providing a comfortable situation for them. Nazara (2011) explained that many times English learners are not comfortable with the presence of their teachers or friends. The students are afraid of being corrected for their mistakes and feel insecure with their English. The learners are afraid of being laughing stock over something as simple as mispronouncing some easy words or using their accent, for example. Podcast blur out the presence of audience. 
Despite the fact that the recordings can be listened to by some strangers out there, it still does not alter the fact that there are no audience present by the time the students hit the broadcast button. Based on the responses of the students, it can be seen that what might bother them the most is not the presence of the audience, but having people looking at them directly when they are speaking or having an eye-toeye-contact with the audience. It is proven by the fact that there are students who share their recordings to their friends to let them know what they have been doing in the class.

\section{CONCLUSIONS}

Throughout this article, the researcher has provided the description of how the researcher implemented podcast in an English classroom and the researcher has also elaborated how podcast help the students. Just like in any other skill, reading, writing or listening, constant practice is always the key. Thus, it can be concluded that podcast can help students to practice their English-speaking skill because it provides

a comfortable situation that can reduce the students' anxiety and boost their confidence.

Expecting such a breakthrough result from a single activity is surely impossible. Thus, a follow up and additional activities are surely needed aside from the podcast to help the students improving their speaking skill. Teachers can start engaging the students in some two-way-communication activities in between the podcasts or once the students get used to speaking in English. All in all, the researcher will not claim that podcast is the best option to help the students with their speaking skill. Podcast might not provide a natural setting of a real-life conversation. It is a one-way communication where the speakers would not need to expect any form of response. However, podcast can help students - especially new learners - to build their selfconfidence and just the right platform to practice their speaking skill.

\section{REFERENCES}

Abadi, C. P. (2015). Developing Speaking Skill in EFL English Course. Journal on English as a Foreign Language, 5(2), 133. https://doi.org/10.23971/jefl.v5i2.373 
Argawati, N. O. (2014). Improving Students'speaking Skill Using Group Discussion (Experimental Study On The First Grade Students Of Senior High School). ELTIN JOURNAL, Journal of English Language Teaching in Indonesia, 2(2). https://doi.org/10.22460/ELTIN.V2I2.P\%P

Bouzar, S. (2019). Issues in Teaching Speaking to EFL Learners. Education and Linguistics Research, $5(1)$. http://www.macrothink.org/journal/index.php/elr/article/view/14705

Creswell, J. W. (2013). Qualitative Inquiry and Research Design: Choosing among Five Approaches (3rd ed.). SAGE Publications, Inc. http://www.ceilconicet.gov.ar/wp-content/uploads/2018/04/CRESWELLQualitative-Inquaryand-Research-Design-Creswell.pdf

Indrianty, S. (2016). Students' Anxiety In Speaking English (A Case Study In One Hotel And Tourism College In Bandung). ELTIN Journal, 4(1). https://doi.org/10.22460/ELTIN.V4I1.P\%P

Khusniyah. (2019). Enhancing Speaking Skills Through Peer-Teaching Method: A Review in EFL Context. 1 St Conference of English Language and Literature (CELL). https://semnas.untidar.ac.id/wpcontent/uploads/2019/07/Khusniyah_Enhancing-Speaking-Skills-ThroughPeer-Teaching-Method-A-Review-in-EFL-Context.pdf

Loeb, S., Dynarski, S., McFarland, D., Morris, P., Reardon, S., \& Reber, S. (2017). Descriptive Analysis in Education: A Guide for Researchers (NCEE 2017-4023). National Center for Education Evaluation and Regional Assistance. https://files.eric.ed.gov/fulltext/ED573325.pdf

Nazara, S. (2011). Students' Perception on EFL Speaking Skill Development. JET (Journal of English Teaching), 1(1), 28. https://doi.org/10.33541/jet.v1i1.50

Nuraini, K. (2016). The Barriers of Teaching Speaking English for EFL Learners. ELLITE: Journal of English Language, Literature, and Teaching, 1(1). https://doi.org/10.32528/ellite.v1i1.159

Perez, S. (2018, February 22). Anchor's new app offers everything you need to podcast / TechCrunch. Techcrunch.Com. https://techcrunch.com/2018/02/22/anchorsnew-app-offers-everything-you-need-to-podcast-including-free-hosting/

Ratnasari, A. G. (2020). EFL Students' Challenges in Learning Speaking Skills: A Case Study in Mechanical Engineering Department. Journal of Foreign Languange Teaching and Learning, 5(1). https://doi.org/10.18196/ftl.5145

Siagian, U. M., \& Adam. (2017). An Analysis of Students' Anxiety in Speaking. JOURNAL ANGLO-SAXON, 8(1), 3-9. https://www.journal.unrika.ac.id/index.php/jurnalanglosaxon/article/viewFile/978/774

Widiati, U., \& Cahyono, B. Y. (2006). The Teaching Of EFL Speaking In The Indonesian Context: The State Of The Art. Journal Bahasa Dan Seni, 34(2). http://journal2.um.ac.id/index.php/jbs/index 
Xu, J. (2011). Second Language Learners and Their Self-confidence in Using English: A Social Constructive Perspective - Asian EFL Journal : Asian EFL Journal. The Asian EFL Journal, 13(3), 246-271. https://www.asian-efl-journal.com/main-editionsnew/second-language-learners-and-their-self-confidence-in-using-english-asocial-constructive-perspective/

Zuhriyah, M. (2017). Storytelling to Improve Students' Speaking Skill. English Education: Jurnal Tadris Bahasa Inggris, 10(1), 119. https://doi.org/10.24042/ee-jtbi.v10i1.879 